\title{
A Study of Customer Service Agent's Pragmatic Identity Construction in Complaint Responses
}

\author{
Cheng Huang ${ }^{1} \&$ Ping Liu ${ }^{1}$ \\ ${ }^{1}$ School of English for International Business, Guangdong University of Foreign Studies, Guangzhou, China \\ Correspondence: Ping Liu, School of English for International Business, Guangdong University of Foreign Studies, \\ No.2 Baiyundadaobei, Guangzhou 510420, P.R.China. Tel: 0086-150-1309-5022. E-mail: 200110438 @ \\ oamail.gdufs.edu.cn
}

Received: June 16, 2021; Accepted: September 22, 2021; Published: September 26, 2021

This study has been supported by the project (16BYY193) "The socio-cognitive approach to metapragmatic utterances in BELF interactions", funded by the National Planning Office of Philosophy and Social Sciences, The National Social Science Fund of China.

\begin{abstract}
Positioned within rapport management theory proposed by Spencer-Oatey, this article investigates the customer service agent's pragmatic identity construction in complaint response calls. Drawing on data of 42 complaint handling recordings from the customer care center of a Chinese airline company, this study tries to address these three research questions: 1) What types of pragmatic identities do the customer service agents construct in complaint response calls? 2) How are these pragmatic identities constructed through rapport management strategies? 3) What interpersonal functions do these pragmatic identities perform? By adopting a qualitative research method, this study has found that the agents mainly construct three default identities and one deviational identity in complaint response calls by employing nine rapport management strategies from four rapport management domains. These different pragmatic identities mainly perform three kinds of interpersonal functions: support face needs, support sociality rights and obligations, and support interactional goals. The findings further validates the feasibility of rapport management theory in the study of identity construction, and provides new ideas for future study on pragmatic identity construction in institutional communications.
\end{abstract}

Keywords: pragmatic identity, identity construction, rapport management, complaint response, customer service agent

\section{Introduction}

Identity has always been an important research object in many academic fields. A lot of scholars have studied identity from sociology, psychology, social psychology, etc and have made fruitful results. These studies all hold that identity is static and pre-determined in communication. With the postmodern turn of identity studies (Benwell \& Stokoe, 2006, p. 4) from essentialism to social constructivism, study on identity has also become a hot topic in pragmatics in recent years (Chen, 2009; Li and Ran, 2015; Ran, 2007; Ren, 2012; Yuan, 2013).

Different from previous studies on identity from essentialism, scholars from the pragmatics field believe that identity is not predetermined but can be shaped and changed in the context of dynamic communication. Based on this, Chen (2013) puts forward the concept of pragmatic identity for the first time and thinks that pragmatic identity can be constructed dynamically according to communicator's communicative purposes. "These communicative purposes can be transactional or interpersonal or both in interaction" (Brown \& Yule, 1983, p. 98; Ran, 2012, p. 1).

However, "The pursuit of interpersonal harmony is an important embodiment of human rationality and that communicators taking measures to maintain a harmonious relationship with their interlocutors becomes a normal state in communication" (Ran, 2012, p. 2). Especially in those customer complaints, because the customer service agent's response to customer's complaints can influence the customer's service experience as well as the company's image. Therefore, when dealing with the customer's complaints, the agents not only need to solve the customer's problems but also need to maintain a harmonious relationship with the customers to maintain the company's image as well as the customer's loyalty. During the process of the interaction between the customer 
service agents and the customer in complaint response calls, how do the customer service agents construct different pragmatic identities through linguistic choice to deal with complaints as well as maintain rapport?

Based on Spencer-Oatey's rapport management theory (2008), this study tries to investigate the customer service agent's pragmatic identity construction in complaint response calls. By collecting the data from the customer care center of a Chinese airline company, this study intends to gain insights into the types of pragmatic identity constructed by the agents in complaint response calls, the rapport management strategies employed to construct these pragmatic identities and the interpersonal functions performed by these pragmatic identities.

\section{Literature Review}

\subsection{Identity and Identity Construction}

Identity is a common but essential aspects of human life, it originally belongs to philosophical category, meaning "the homomorphism in difference or the same problem in variety is the same" (Zhang, 2006, p. 39). However, after several decades of development, identity has become a major topic in philosophy, sociology, psychology, social psychology, culture, social science, etc. From various perspectives and adopting various approaches, scholars from different academic fields have defined identity in different ways. From sociological perspective, Marx and Engels define identity as "identity refers to one's origin, status and qualification. It is people's status in a certain social relationship, so everyone has an identity” (Marx and Engels, 1997, p. 18). Stryker defines identity as "the social attribute of an individual or a group in society, such as age and gender, or people's status or positions in social relations or the roles they play in society" (Stryker, 1987, p. 90). These two definitions all emphasize the indivisibility of the relationship between identity and social relations.

From the perspective of psychology, psychologist such as Tajfel (1978) regards identity as people's different group categories such as ethnicity and nationality. However, these two perspectives only emphasize people's stable aspects in communication. Adopting a socio-psychological approach, Simon (2004) argues that identity is the result of a self-interpretation process that takes shape at the meso-level of the immediate interaction context.

With the development of social constructivism, many scholars explore identity in a more comprehensive manner. Tracy and Robles (2002) put forward two approaches to dealing with both the static and dynamic nature of identity. Tracy holds that "identity should be considered as people's stable features that have existed prior to any particular situations, at the same time, it is also a dynamic and situated accomplishment that can be enacted through talk and changed from one occasion to another" (Tracy, 2002, p. 17). Regarding identity as a tool and achievement, Antaki and Widdicombe (1998) propose an approach that is related to but different from Tracy's and Simon's approach, they think that "identity is something that is used in talk". Considering identity as "a component of context for talk-in-interaction", Zimmerman (1998) argues that "identity as a component of context" is relevant to the development of interaction. Taking a social-cultural linguistic approach, Bucholtz and Hall (2005) define identity as "social positioning of oneself and the other". These definitions all emphasize the dynamic interaction between identity and context.

Based on identity defined by previous scholars, Chen (2013) puts forward the concept of pragmatic identity and defines it as "pragmatic identity is the presentation of a person's specific social identity in a specific communicative context, and it is the result of the communicator's choice when making or understanding a specific utterance or discourse" (Chen, 2013, p. 27). Yuan (2011) defines identity as "communicator's social positioning of self and others to meet communicative purposes" and points out that "pragmatic identity is the identity that is used by communicators to satisfy communicative needs" (Yuan, 2011, p. 28). Ren (2012) defines identity as "identity is who we must be/can be/might be, which is linguistically constructed for the moment, in a social and communicative network, to satisfy communicative needs in a dynamic interaction. It is communicative in essence no matter whether it is personal or social" (Ren, 2012, p. 23). Follow the pragmatic identity defined by these three scholars, we define pragmatic identity in this study as "the relevant pragmatic resources that the communicators invoke to achieve their communicative needs through social positioning of others and themselves". There are three characteristics of this definition: Firstly, identity is related to communicative needs. Pragmatics focuses on the realization of communicative purposes and the construction of different identities may ultimately lead to the realization of communicative needs. These communicative needs can be pre-established or determined as the conversation progresses and communicative needs should include specific context needs and face needs. Secondly, identity is relevant to people's social positioning of others and themselves. Therefore, communicators need to consider the identity characteristics of the speaker and the hearer when choosing or constructing their identities. Thirdly, identity can be used as a pragmatic resource. "As a communicator in conversation, in order to achieve communicative purposes, the speaker always generates pragmatic power through the invocation of pragmatic 
resources and strives to achieve the balance between pragmatic power and communicative needs" (Chen, 2014, p. 702).

Identity construction has been widely studied in the context of written discourse (Li, 2016; Li \& Deng, 2019; Sun, 2015), academic interaction (Chen \& Li, 2016; Guo, 2016; Ren, 2012; Zhong, 2018), daily communication (Davies, 2019; Sierra, 2019) etc. Recently, pragmatic identity construction in business context has received the attention among scholars and they have studied pragmatic identity construction in different business contexts. By adopting adaptation theory, Yuan $(2011,2013)$ investigates the medical consultant's pragmatic identity construction in business Phone-in, it is found that the consultant constructs different types of pragmatic identities to perform different functions and thus to facilitate the business deals. Chen (2018) analyzes the "identity traps" from the perspective of critical pragmatics to explore the types, linguistic strategies and distributions of identity construction in real estate ads. The study uncovers the "identity traps" the advertisers set up, which contributes to our understanding of the genre features and persuasion arts of commercial ads.

Some scholars examine the relationship between humor and identity construction in customer complaints. For example, Orthaber (2019) explores the aggressive humor used by online customers to express their dissatisfaction with the services provided by a state-owned transport company. Results indicate that the customers can create ingroup identity through the use of humor by aligning with each other. Vöge (2010) employs the approach of conversation analysis to explore laughter in complaints in business meetings. The findings reveal that organizational hierarchical identities can be shown through laughter in complaints. Although these two studies do not identify the specific identity types, they all show the dynamics of identity constructions in complaints. However, little attention has been paid to the study of the dynamic interactions between the complainant and the complainee in terms of pragmatic identity construction. In business complaints, the customer service agent not only has to deal with complaints, but also has to maintain rapport with the customer. In this process, the agent may construct a variety of pragmatic identities. In view of this, this study intends to explore the customer service agent's pragmatic identity construction in complaint response calls to extend the research scope of pragmatic identity construction.

\subsection{Customer Complaint Responses}

Previous studies on customer complaint responses mainly focus on response strategies (Davidow, 2003; Karatepe, 2006), effects of responses (Davidow, 2003; Karatepe, 2006) and interpersonal concerns in handling complaints (Drew \& Walker, 2009; Ekström \& Lundström, 2014). Most of these studies are conducted from the perspective of service management (Anna, Daniel \& Mount, 2003; Doga, 2017; Refiana, 2012), consumer psychology (Liao \& Keng, 2013; Min, Joireman \& Kim, 2019), consumer marketing (Hutzinger \& Weitzl, 2019; Melancon \& Dalakas, 2018), linguistics (Ho, 2017; Zhang \& Vásquez, 2014) etc. to provide some suggestions for effective management of customer complaints.

Specific to the study of customer complaint responses in pragmatics, scholars have also conducted an in-depth study on online reviews and complaint calls. Ho (2017), Zhang and Vásquez (2014) examine the review responses written by hotel management on TripAdvisor to manage consumer dissatisfaction. These two studies all provide some empirical strategies for hotel management to response negative online reviews. However, they don't explore the customer's perceptions and reactions to various strategies in responding to customer's dissatisfactions. In view of this, in another study, Ho (2018) explores the effectiveness of hotel management's responses to negative online reviews from the customer's perspective by inviting the dissatisfied customers to read the responses and collecting their views. Results indicate that there is a difference in the use of moves and metadiscourse between effective and less effective responses, which can be used to manage rapport and achieve persuasion. Feng \& Ren (2019) examine Chinese management responses to negative online consumer reviews and rapport management because there is a lack of attention being paid to Chinese reviews. It identifies 14 relational acts and finds that review valence plays an important part in the retailer's use of relational acts for managing rapport.

Some scholars explore service provider's response strategies to customer complaint calls to see how complaints are terminated. For example, by employing conversation analysis method, Ekström and Lundström (2014) examine the complaint calls to the government authority for student loans in Sweden to explore the termination of complaints, they analyze the design and positioning of different transitional devices. The findings are in line with some observations in previous research. It indicates that complaint responses involving stance balance and affiliation in complaint responses are always avoided in institutional interaction. Kevoe-Feldman (2018) investigates the interactional work between customers and service representatives to suppress complaint by analyzing customer service calls to an electronic repair company, the findings have some implications for complaint management in service encounters. Some researchers examine the dynamic interactions of complaint calls in terms of face concerns. Orthaber and Marquez-Reiter (2011) explore the construction of complaints in 
calls to a public transport company in slovenia, it reveals that complaints are constructed through a step by step manner and face concerns are observed between the complainants and complainees during the complaint sequences. In another study, Marquez-Reiter (2013) investigates how telephone conversationalists initiate, develop and revisit a complaint in a Latin American for-profit service encounter through an overtime development of complaint. Results show that complaint is carefully launched and becomes salient once the other party does not align with it. These two studies all reveal that the ways the agent responses to complaints can reflect the company's business practices.

As noted above, pragmatic studies on customer complaint response is various. Researchers have conducted studies on customer complaint response both on written discourse (online reviews) and spoken interaction (complaint calls). During the complaint interaction between the customers and the customer service agent, the agent may adopt a variety of linguistic strategies to deal with complaints. Since discursive practice and identity construction are interrelated, the agent may also construct various identities in the process of complaint handling. However, as noted above, it is relatively scarce in the study of customer service agent's pragmatic identity construction in complaint responses among previous studies. Therefore, this study intends to investigate customer service agent's pragmatic identity construction to broaden the study scope of pragmatic identity construction in different context.

\section{Rapport and Rapport Management}

\subsection{Components of Rapport Management}

"Rapport management refers to the management of harmony-disharmony among people" (Spencer-Oatey, 2008, p. 13). This theory is derived from Brown and Levinson's (1987) face management. Compared with face management, the scope of rapport management is broader. It not only examines how language constructs, maintains and threatens social relationship, but also includes how to coordinate social rights and obligations and interactional goals. According to Spencer-Oatey, there are three components of rapport management theroy: the management of face, the management of sociality rights and obligations, and the management of interactional goals.

The first component is the management of face. Face management involves the management of face sensitivities. Spencer-Oatey defines it as "the positive social value a person effectively claims for himself by the line others assume he has taken during a particular contact" (Spencer-Oatey, 2008, p. 13). She further divides face into two aspects: quality face and identity face. Quality face involves the positive evaluation of personal image and quality. Identity face is concerned with individual's identity position, social role, social value and status in the group. Communication can not only affect individual's face, but also affect the face of both sides in communication and the face of the group to which the individual belongs.

The second component is the management of sociality rights and obligations. It includes equity rights and association rights. Equity rights ensure that people have the right to equal treatment, they not only have the right to be respected and cared for by other people, but also have the right to refuse to be driven, forced, misused and exploited by others. Association rights refer to people's need to participate in social activities in order to maintain relationships with others. It is realized by means of interactional involvement-detachment and affective involvement-detachment.

The last component is the management of interactional goals. "It refers to the specific task and/or relational goals that people may have when they interact with each other" (Spencer-Oatey, 2008, p. 14). When people communicate with each other, they always have specific communicative goals. These communicative goals can be relational or transactional. Relational goals attach importance to maintaining the relationship, while transactional goals aim to accomplish a specific task.

If any element of these three components is not maintained, the harmonious relationship will be threatened. On the contrary, when these three components are well managed, harmonious relationship can be maintained.

\subsection{Rapport Management Domains and Strategies}

Brown and Levinson (1987) suggest that it is generally in every participant's best interest to maintain each other's face for losing face is a painful experience. Therefore, "every language provides a very wide range of linguistic options that can be used for managing face and sociality rights, and hence for managing rapport" (Spencer-Oatey, 2008, p. 21). According to Spencer-Oatey, there are five rapport management domains that can be used to manage rapport, which are illocutionary domain, discourse domain, participation domain, stylistic domain and non-verbal domain. In each domain, she also identifies some rapport management strategies. Table 3-1 presents the definition and rapport management strategies of each domain. 
Table 3-1 Rapport management domains and strategies (Spencer-Oatey, 2008)

\begin{tabular}{|c|c|c|}
\hline Domain & Definition & Strategies \\
\hline \multirow{3}{*}{$\begin{array}{l}\text { Illocutionary } \\
\text { domain }\end{array}$} & \multirow{3}{*}{$\begin{array}{l}\text { The rapport-threatening/rapport } \\
\text { enhancing implications of } \\
\text { performing speech acts }\end{array}$} & The selection of speech act components \\
\hline & & The degree of directness-indirectness \\
\hline & & The type and amount of upgrades/downgrades \\
\hline \multirow{3}{*}{$\begin{array}{l}\text { Discourse } \\
\text { domain }\end{array}$} & \multirow{3}{*}{$\begin{array}{l}\text { The discourse content and } \\
\text { discourse structure of an } \\
\text { interchange }\end{array}$} & Topic choice \\
\hline & & $\begin{array}{l}\text { Topic management (for example, the inclusion/exclusion } \\
\text { of personal topics) }\end{array}$ \\
\hline & & The organization and sequencing of information \\
\hline \multirow{3}{*}{$\begin{array}{l}\text { Participation } \\
\text { domain }\end{array}$} & \multirow{3}{*}{$\begin{array}{l}\text { The procedural aspects of an } \\
\text { interchange }\end{array}$} & $\begin{array}{l}\text { Turn-taking (overlaps and inter-turn pauses, turn-taking } \\
\text { rights and obligations) }\end{array}$ \\
\hline & & The inclusion/exclusion of people present \\
\hline & & $\begin{array}{l}\text { The use/non-use of listener responses (verbal and non- } \\
\text { verbal) }\end{array}$ \\
\hline \multirow{3}{*}{$\begin{array}{l}\text { Stylistic } \\
\text { domain }\end{array}$} & \multirow{3}{*}{$\begin{array}{l}\text { The stylistic aspects of an } \\
\text { interchange }\end{array}$} & Choice of tone (for example, serious or joking) \\
\hline & & Choice of genre-appropriate lexis and syntax \\
\hline & & $\begin{array}{l}\text { Choice of genre-appropriate terms of address or use of } \\
\text { honorifics }\end{array}$ \\
\hline \multirow{3}{*}{$\begin{array}{l}\text { Non-verbal } \\
\text { domain }\end{array}$} & \multirow{3}{*}{$\begin{array}{l}\text { The non-verbal aspects of an } \\
\text { interchange }\end{array}$} & Gestures and other body movements \\
\hline & & Eye contact \\
\hline & & Proxemics \\
\hline
\end{tabular}

\subsection{Analytical Framework}

The analytical framework in this study is based on Chen's (2013) identity construction theory and Spencer-Oatey's (2008) rapport management theory.

According to Chen (2013), communicators dynamically choose specific identity in specific context to satisfy communicative needs. That is to say, in order to meet specific communicative needs, communicators will make specific pragmatic identity choices and then construct these identities through discourse choices to achieve certain communicative effects. The context will also influence this dynamic process.

Actually, identity construction and interpersonal relationship are interrelated. Brown and Levinson (1987) hold that it is generally in every participant's best interest to maintain each other's face. In normal situations, communicators in communication not only convey or gain information through their interaction, but also have a tendency to maintain rapport with each other. To achieve these two purposes, communicators may construct different identities through different linguistic choice. In this way, their communicative purposes are achieved.

In the specific context of complaint responses, driven by communicative purposes, the agent will make choices to construct different identities. These identities are constructed through different rapport management strategies from five rapport management domains to achieve different interpersonal functions, namely, support face needs, support sociality rights and obligations, and support interactional goals. In this way, the agent's communicative purposes can be achieved.

\section{Research Questions}

This study intends to explore customer service agent's pragmatic identity construction in complaint response calls from the perspective of rapport management. It is assumed that identity is not static but can be dynamically constructed, and it is a tool and resource for the speaker to choose to satisfy his/her communicative needs. Based on rapport management theory, this study aims to address the following three questions:

(1) What types of pragmatic identities do the customer service agents construct in complaint response calls?

(2) How are these pragmatic identities constructed through rapport management strategies? 
(3) What interpersonal functions do these pragmatic identities perform?

\section{Data and Method}

\subsection{Data Collection and Description}

The data used for analysis in this study are collected from the customer care center of a Chinese airline company. In order to keep confidentiality, the name of the company has all been represented as "XXXX" in this article. The company is one of the three major airline companies in China and the customer care center in this company is responsible for handling complaints from customers. The whole process of handling complaints should be recorded according to the regulations of the company. So we directly get the recordings from the customer care center. These recordings are all outbound complaint handling calls from the company because the customers have already written a complaint email to the company through the company's official website before. In total, we obtain 42 complaint handling recordings (about 7.5 hours) from the customer care center and they are randomly given to us. Participants in the recordings are the customer service agents from the customer care center and the customers from all over the world. The languages they use are mostly English except for a few Chinese customers who speak Chinese.

\subsection{Identity Classification Criteria}

The criteria for classifying identities in the present study is inspired from Ren's (2012) doctoral dissertation. Ren (2012) investigates the expert advice-giver's identity construction in academic advising interaction from five $\mathrm{PhD}$ dissertation proposal presentation meetings. In his study, he classifies identities into two categories: default identity and deviational identity. "Default identity means who people must be in interaction and deviational identity means who people can/might be in interaction" (Ren, 2012, p. 4). Ren further divides default identity into several subcategories according to the discussion on the leader's personal identity by Ho (2010a, 2010b), personal identity proposed by Tracy (2002) and Simon's (2004) self-aspect model of identity. After a preliminary analysis of the data, the author finds that the customer service agent also constructs these two types of identities---default identity and deviational identity---when handling complaints. So the author adopts Ren's (2012) identity classification criteria. It is obvious that the agent identity is the default identity of the customer service agent in complaint response calls because these identities are pre-inscribed and expected to construct when handling complaints. When identifying default identities, the author pays particular attention to the agent's personality, attitudes and character showed when handling complaints. Deviational identities are those identities deviating from agent identity and they are identified based on Tracy's interactional identity and relational identity. Table 5-1 presents some examples of the criteria when identifying each type of identity.

Table 5-1 Examples of the criteria when identifying each type of identity

\begin{tabular}{|c|c|c|}
\hline Pragmatic identity & Examples of utterance & Personality/attitudes/character \\
\hline \multirow{3}{*}{ Default identity } & $\begin{array}{l}\text { And we will try to solve this regulation because the } \\
\text { regulation is very very trouble. }\end{array}$ & Considerate \\
\hline & $\begin{array}{l}\text { I will talk with our staff and help you make to do this } \\
\text { refund and to make the money back as soon so } \\
\text { possible. OK. And now I will help you to do that. }\end{array}$ & Accountable \\
\hline & $\begin{array}{l}\text { because your ticket should not be changed because } \\
\text { of original regulation. }\end{array}$ & Powerless \\
\hline Deviational identity & $\begin{array}{l}\text { 他们那边应该有负责这个业务的专家 } \\
\text { (they should have some experts responsible for this) }\end{array}$ & \\
\hline
\end{tabular}

\subsection{Data Analysis}

The procedures to analyze the data are carried out to answer the three research questions raised in the first chapter.

First, the recordings are transcribed into transcripts by the author according to transcription conventions of discourse analysis. In order to keep the exhaustiveness of the data, all the information contained in the data is transcribed, including these audible spoken words, pauses, overlapping texts, interruptions and intonations, etc. After the transcription, the author makes a detailed investigation of the data turn-by-turn to find out the types of identities constructed by the agent according to the identity classification criteria mentioned above. After that, the author identifies the linguistic strategies employed by the agent for each identity construction based on SpencerOatey's rapport management strategies from five domains. According to Spencer-Oatey, there are five rapport 
management domains that can be used to manage rapport, they are illocutionary domain, discourse domain, participation domain, stylistic domain and non-verbal domain. When identifying rapport management strategies, the author pays particular attention to the agent's speech acts, discourse content, discourse structure and management of topic in handling complaints. Next, the author sorts out these rapport management strategies that the agents employ for each identity construction to analyze the data. Finally, the interpersonal functions of the identities constructed by the agent are analyzed to interpret the potential motives of each identity construction from the perspective of rapport management.

\section{Findings and Discussion}

\subsection{Types of Identities Constructed by Customer Service Agent}

After the analysis of the data based on the identity classification criteria described above, the author has found that the agent mainly constructs three types of default identities and one type of deviational identity in complaint response calls. The default identities are considerate agent, accountable agent and powerless agent, and the deviational identity is layperson. These four types of identities are not static but dynamically constructed in the process of handling complaints. The following four extracts show the specific examples of each type of identity the agent constructs in complaint response calls.

\subsubsection{Considerate Agent}

\section{Extract 1}

(Context information: the customer complains about the company's services because he cannot talk to the supervisor.)

$01 \mathrm{C}$ : When I call other line, other airline, the issue, I want to say is, well, let me talk to your supervisor, and generally most of the time, yes. No problem, and you know, it wasn't so, you know, I believed, it is impossible to create a regulation that covers all situations, all right? So therefore that's why you need a supervisor to handle the situation, OK?

$02 \mathrm{~A}$ : Of course. And so all of the problems, all the questions, and we will delivery them again, and then we must do that to change that because our service is [so] bad, and it's not good enough just international airlines, and we have to do the better and as soon as possible. It is what we should do that.

This extract shows the considerate agent identity construction. As can be seen from the context information, the customer is not satisfied with the company's services because he cannot talk to the supervisor although the agent cannot deal with the customer's problems. In line 01 , the customer makes a comparison between the company and other airline company to point out the existing problems of the company's regulation. Then in line 02 , the agent acknowledges the problems of the regulation and the bad services of the company to comfort the customer, which shows his consideration to the customer. In this way, the agent constructs a considerate agent identity.

6.1.2 Accountable Agent

\section{Extract 2}

(Context information: the customer asks the agent to change the flight for him.)

$01 \mathrm{C}$ : Is there any other choice?

02 A: No, for the morning flight, Guangzhou to Dubai, no seat available.

$03 \mathrm{C}$ : No seat available at the moment?

04 A: Yeah. EK Flight, no seat available. XXXX only has the afternoon flight.

$05 \mathrm{C}$ : [What about] if there is another airline can take me to Guangzhou (0.1) now? At 6:00?

06 A: [No], We tried. Nanjing is not a fit airport. No 3:00, no. The only one is this one.

07 C: Okay.

08 A: So you will take this flight?

$09 \mathrm{C}: \mathrm{OK}$. But if I have other choices?

10 A: [No]. I'm so sorry. (0.2) So I will ask the related department to do it again to see whether successfully. In this extract, the customer wants to change his flight. However, there is no seat available for the flight to the customer's destination. In line 08 , the agent makes a confirmation about the customer's choosing flight. As can be 
seen from the customer's answer in line 09 , the customer seems to accept the flight reluctantly. So the agent makes the commitment to enquire the related department to see whether they can change the ticket for the customer. This shows the agent's being accountable as a service representative of the company who is willing to address the customer's problems. In this way, constructing an accountable agent identity.

6.1.3 Powerless Agent

\section{Extract 3}

(Context information: the customer asks the agent to return the transfer fee.)

$01 \mathrm{C}$ : Yeah, that's why I said that they charged me for the second fee. (???) refund the money. 75 yuan, US dollars.

02 A: I'm sorry, because this fee was charged by bank. So XXXX [couldn't] offer it. We're so sorry for that, but we couldn't refund or offer for this fee.

$03 \mathrm{C}$ : The lady this morning, she told me something that I could-should call the number, I called this morning. And this number, I think, is not in United States. She told me to call this number, and I don't know the number was in Canton, China. So that happened, The bad thing happened.

$04 \mathrm{~A}$ : Yes. I mean that, because (interrupt)

$05 \mathrm{C}$ : Your guys caused this thing happen. You told me something about RMB balabala. (???) And then you mentioned the currency and calculated RMB into US dollars. So they charge me a second fee.

$06 \mathrm{~A}$ : Yes, I mean that, because the rule is different by every moment, and the transfer fee is accounted by the bank. (???) We couldn't offer the refund.

$07 \mathrm{C}$ : So anyway, you couldn't (0.2) give the refund?

08 A: No, we couldn't. We're so sorry.

In this extract, the customer mistakenly calls the customer care center of the company in Canton due to time lag and the customer has paid the transfer fee for his call. So the customer wants to refund the transfer fee. In line 02 , the agent has explained to the customer that the transfer fee is charged by the bank instead of the company. However, the customer thinks that the company should take the responsibility. Then in line 06, the agent repeats what he mentioned before to make the explanation that he cannot refund the transfer fee because it is charged by the bank. This repetition shows the agent's powerless aspect to help the agent because it is beyond his power. In this way, the agent constructs a powerless agent identity.

\subsubsection{Layperson}

\section{Extract 4}

(Context information: the agent suggests that the customer should make a complaint about XXX Bank because XXX bank opens the membership account for the customer without his permission.)

$01 \mathrm{~A}$ : 那我建议您可以投诉 XXX 银行那边的,他无端给您办理这种联名卡, 又没有跟你说。

$02 \mathrm{C}$ : 我现在投诉 XXX 银行还行吗?

$03 \mathrm{~A}$ : 您不是说没有跟您说清楚嘛, 他们那边给您办的, 肯定要有这个义务去给您讲清楚相关的积分或者 是使用卡的一个情况。

$04 \mathrm{C}$ : 那你们去找 XXX 银行。

$05 \mathrm{~A}$ : 我们没办法去给您联系 XXX 银行的, 我们也不太清楚他们具体的操作什么的, 他们那边应该有负 责这个业务的专家, 我只能根据我们会员手册的条款给您做解释。

$01 \mathrm{~A}$ : So I suggest you should complain about the staff in XXX Bank, they register a bank card for you without your permission.

$02 \mathrm{C}$ : Can I make the complaint now?

$03 \mathrm{~A}$ : You just said they did not inform you of the registration of the bank card. Now that they registered the bank card for you, they have the obligation to tell you about the special offer of accumulated points.

$04 \mathrm{C}$ : Can you make the complaint for me?

05 A: We cannot do it for you, we do not know their specific operation, they should have some experts responsible for this. We can only make explanation to you according to the membership book.

In this extract, the agent suggests that the customer should complain about XXX Bank because XXX Bank opens the membership account for the customer without his permission. However, in line 04, the customer asks the agent 
to complain about what XXX Bank has done. Then in line 05, the agent gives the explanation to the customer by referring to “我们没办法去给您联系 XXX 银行的, 我们也不太清楚他们具体的操作什么的, 他们那边应 该有负责这个业务的专家” (we cannot do it for you, we do not know their specific operation, they should have some experts responsible for this). As can be seen from this reply, the agent constructs a layperson identity by referring to the expert in XXX Bank for his lacking specific knowledge of the operation in XXX Bank.

\subsection{Rapport Management Strategies Employed to Construct Identities}

According to Tracy and Robles (2013), identity construction and discursive practice are interrelated. The discursive practice a person chooses can decide his corresponding identity, and the identity a person chooses can also influence his discursive practice. Based on the above identity identification, the agent constructs four types of pragmatic identities in complaint response calls. These pragmatic identities are constructed through different rapport management strategies. Table 6-1 shows the rapport management strategies the agent employs to construct each type of identity.

Table 6-1 Rapport management strategies employed to construct identities

\begin{tabular}{c|l|l}
\hline Pragmatic identity & \multicolumn{1}{|c|}{ Strategies } & \multicolumn{1}{c}{ Domain } \\
\hline \multirow{4}{*}{ Considerate agent identity } & Acknowledging problems & Discourse domain \\
\cline { 2 - 3 } & Making suggestions & Discourse domain \\
\cline { 2 - 3 } & Making apologies & Illocutionary domain \\
\hline \multirow{2}{*}{ Accountable agent identity } & Making commitments & Discourse domain \\
\cline { 2 - 3 } & Making explanations & Discourse domain \\
\hline \multirow{3}{*}{ Powerless agent identity } & Making apologies & Illocutionary domain \\
\cline { 2 - 3 } & Changing topic & Discourse domain \\
\cline { 2 - 3 } & Making repetition & Stylistic domain \\
\hline Layperson identity & Making identity reference & Participation domain \\
\hline
\end{tabular}

\subsection{Interpersonal Functions of Agent'S Pragmatic Identity Construction}

"Language communication has two basic purposes. One is to convey information or to do things; the other is to maintain interpersonal relationship" (Ran, 2012, p. 5). In complaint response calls, the agent not only needs to deal with the customer's complaints, but also needs to comfort the customer to maintain a harmonious relationship with the customer. In this way, achieving service recovery. According to Spencer-Oatey's rapport management theory (2008), language can achieve three major interpersonal functions: support face needs, support sociality rights and obligations and support interactional goals. There are two subparts in each interpersonal function. Support face needs include support self and other's quality face and identity face, support sociality rights and obligations include support self and other's equity rights and association rights and support interactional goals include support relational goals and transactional goals.

Actually, agent's pragmatic identity construction and interpersonal relationship are interrelated. The agent may construct different types of identities to achieve certain communicative purposes. That is to say, to support self and the customer's quality face and identity face, equity rights and association rights, and interactional goals. These interpersonal functions will be analyzed with specific examples in the following part.

\subsubsection{Support Face Needs}

According to Spencer-Oatey's rapport management theory (2008), face consists of quality face and identity face. Quality face refers to communicator's basic desire to receive a positive evaluation in terms of their personal qualities such as competence, intelligence, appearance and conduct, etc., which involves self-esteem or personal image. While identity face refers to communicator's basic desire to be recognized and maintained in terms of their identity and role, which is closely related to their sense of public worth. The following examples elaborate the identities constructed to achieve these interpersonal functions. 


\subsubsection{Support Self Quality Face and Identity Face}

In complaint response calls, the agents may dynamically construct pragmatic identities to support their own quality face and identity face when their quality face and identity face are threatened. Extract 5 and extract 6 are two examples in point.

\section{Extract 5}

(Context information: the customer calls to inquire the reason why his money has not been refunded by the company.)

$01 \mathrm{~A}$ : Yes. The money will get back. We will refund the money today. And we said that the money will refund by XXXX today.

02 C: Right. OK.

03 A: OK. And if you didn't get the money and you can get-eh, give us phone call again. It's OK. Or you can check out by your issue bank.

$04 \mathrm{C}$ : I am not calling you again. I won't choose XXXX again. I am not calling you again. I will go to [book my ticket] on somewhere, reliable. (???)

$05 \mathrm{~A}$ : Yes.

$06 \mathrm{C}$ : Can you ensure the refund?

$07 \mathrm{~A}$ : Yes, because we said that the money- the ticket- the order will be refunded by XXXX.

In this extract, the customer complains that his money still has not been refunded by the company although he has called the agent before and the customer becomes very emotional. Then in line 01 , the agent makes commitment that the company will refund the money today and further makes suggestion that if the customer doesn't get the money, he can call the agent again or check the issue bank in line 03. In the previous interaction, the customer says he will not book any tickets in the company anymore because he thinks the agent is not responsible. By making commitment, the agent constructs an accountable agent identity to support his quality face. Then in line 04, the customer repeats what he mentioned before and says he will go to somewhere else reliable to book his ticket, which is face-threatening to the agent and the company by making this negative comment on the company. Then in line 07 , the agent makes commitment again by saying that his money will be refunded by the company to support his identity face as a member of the company. As can be seen from this extract, the agent constructs an accountable agent identity by making commitment to support his quality face and identity face.

\section{Extract 6}

(Context information: the customer asks the agent to change the flight for him. However, XXXX does not have the control right of the tickets.)

$01 \mathrm{C}$ : If I fly on time, can I catch the flight?

$02 \mathrm{~A}$ : [No.] Cannot catch it. Just now. I check that the departure time is 4:35, arrives in Guangzhou is about 7:00 pm. But Guangzhou to Dubai, the morning flight, no seat available. We cannot make a booking because actually it's operated by the EK company. So it means that you need to take tomorrow afternoon flight Guangzhou to Dubai. And then you will arrive in Bali at generally (.) 31 the next day.

$03 \mathrm{C}$ : Oh. (0.2) So there is not flight that I can go now?

04 A: Nanjing to Guangzhou should 4:35. I [can] change for another airline.

$05 \mathrm{C}$ : Check it for me. I want to go to Dubai today. [Please].

06 A: [No flight]. I'm so sorry.

$07 \mathrm{C}$ : Please book me another airline from Nanjing to Guangzhou.

$08 \mathrm{~A}$ : So, $\mathbf{( 0 . 5 )}$ can you accept the new flight information we organized for you? If you accept, we can try to do it again. Do you need a message?

In this extract, the customer asks the agent to change the ticket for him because he wants to go home on the day of complaints. However, due to the tight schedule, the customer may not catch the flight. So in line 01, the customer asks whether he can catch the flight if he flies on time. Then the agent replies that there is no seat available on the morning flight although he can arrive on time and he cannot make a booking for the customer because the company does not have the control right of the ticket. Then in line 03 , the customer wants to make a confirmation again and asks "So there is not flight that I can go now?" However, the agent does not answer the question directly. Instead, 
he makes a topic change to construct a powerless agent identity to stress the departure time of the flight and gives another offer that he can change another flight for the customer to support his quality face. The customer does not seem to give it up because in line 05 and line 07 , he still requires the agent to change the flight for him. In line 08 , the agent makes a topic change again to ask the customer whether he can accept the new flight and says if the customer accepts, he can try to change it for the customer. Through this topic change and offering another solution, the agent still constructs a powerless agent identity to support his quality face because he does not have the control right of the ticket.

\subsubsection{Support other's Quality Face and Identity Face}

When handling complaints, the customers may sometimes mention their personal quality. When it happens, the agents may always construct pragmatic identities to support the customer's quality face. In addition, when the agents hear what the customers have suffered due to the inconvenience brought by the company, they may also show sympathy to the customer to construct a considerate agent identity to support the customer's identity face. The following two extracts show the identities constructed to support the customer's quality face and identity face.

\section{Extract 7}

(Context information: the customer mentions his personal quality after the agent acknowledges the problems in the ticket software.)

$01 \mathrm{C}$ : Yeah. You know I am the gross member (???)

$02 \mathrm{~A}$ : Yes.

$03 \mathrm{C}$ : So if you could see my record, I'm a very good customer.

$04 \mathrm{~A}$ : Yes , [I] got it. Because I am thank you to support XXXX, because it is our system problem and we wish that we will do better and better in the future service, and we hope that we will not do these wrong things any longer.

$05 \mathrm{C}$ : OK, thank you.

In this extract, the customer calls to complain about the problems in the ticket software because there is no terminal information in the software when he changes to the English channel. Because of this, the customer almost misses his flight. After the agent acknowledges the problems in the software, the customer mentions his personal quality in line 01 by saying "you know I am the gross member". In line 03 , the customer mentions his personal quality again by referring to his record and directly proves that he is a good customer. Then, the agent makes the compliment by giving a positive answer "yes, I got it" and thanks the customer to support the company and acknowledges the problems again to construct a considerate agent identity to support the customer's quality face. Because the agent understands that it is the problems in the ticket software that give the customer inconvenience. It is not because of the customer's personal quality. Then, the agent makes some promises that they will do better in the future, which further strengthens his considerate agent identity to support the customer's quality face.

\section{Extract 8}

(Context information: the customer complains about the problems in the ticket software.)

01 C: Hello.

02 A: Hello, good morning, sir. This is XXXX Complaint Center. Are you available to talk to now?

$03 \mathrm{C}$ : Yes, I am.

04 A: OK, excuse me, sir. Because we have got a complaint when you board a flight just from Guangzhou to Shanghai on 11th of June.

$05 \mathrm{C}$ : Yes

06 A: Because [in our] software, because when you change to the English channel, but there is not any terminal information in our software.

$07 \mathrm{C}$ : Yeah. [We] almost lost our flight, you know, because(-) the terminal was not mentioned, and this is two. When I went to terminal one (-) and then they said, oh, China (???) Terminal Two. And we checked in almost one minute before the checking counter closed. We almost gonna lose our flight.

$08 \mathrm{~A}$ : Yes. We got all the information for that, and we're very sorry for (disrespect?), because [the] information is [very] importantly, because just you said that you almost miss this flight, because this is a wrong information, because we've made you to the wrong terminal one. 


\section{C: Yes}

This extract is the front part of the interaction of extract 7. The context information is also about the problems in the ticket software. In line 06, the agent directly acknowledges the problems in the ticket software. Hearing this, the customer then complains about what he has suffered due to these problems in line 07. And then, the agent makes the apology to the customer and acknowledges the problems again by using four "because" sentences. These four sentences are all attending to the customer's benefits. As an international airline company, the customer should have received the best service from the company. However, the company failed. By acknowledging problems, the agent shows his consideration to the customer and constructs a considerate agent identity to support the customer's identity face because as a customer, they should have had a better service experience.

\subsubsection{Support Sociality Rights and Obligations}

Sociality rights and obligations is another important part of Spencer-Oatey's rapport management model. It also includes two interrelated aspects: equity rights and association rights. Equity rights is a prerequisite for the realization of interpersonal harmony. It means that communicators should be equally treated in communication, and should not be driven or imposed by their interlocutors. They should enjoy their due rights and interests. Association rights refer to the belief that we are granted the rights to communicate with others to maintain relationship with them, which includes interactional involvement-detachment and affective involvementdetachment. In other words, it means that communicators should be given the opportunity to participate in communication, share their feelings and interests with each other and be properly respected.

\subsubsection{Support Self Equity Rights and Association Rights}

When handling complaints, the agents may sometimes meet some problems that they cannot deal with. However, the customers may still require the agents to handle these problems. This violates the principle of being equally treated in communication. When this happens, the agents may construct pragmatic identities to support their equity rights. Furthermore, in some situations, the customers even condemn the agents when they are angry. This shows the agents are not properly respected and their association rights are threatened. When it happens, the agents may also construct pragmatic identities to support their association rights. The following two extracts are cases in point.

\section{Extract 9}

(Context information: the customer asks the agent to let the manager to deal with the complaint because he is not satisfied with the agent's services.)

$01 \mathrm{C}$ : You're not even a manager?

02 A: Yes.

$03 \mathrm{C}$ : OK. So there must be a manager in your department, Memphis?

$04 \mathrm{~A}$ : I'm sure that's sure because there is no any more answer for that.

$05 \mathrm{C}$ : Okay, find a line to get to your manager, please.

06 A: No, I'm sorry, sir

$07 \mathrm{C}$ : I will be still on the line.

08 A: No, sir.

$09 \mathrm{C}$ : What do you mean "no, sir"?

\section{$10 \mathrm{~A}$ : Because these answers are for $\mathbf{X X X X}$, and are final answer.}

\section{$11 \mathrm{C}$ : So-OK can you give me the President of XXXX?}

\section{A: Because we couldn't offer this information to you, sir. I'm so sorry.}

$13 \mathrm{C}$ : Well, I'm not leaving the phone, Memphis, until you tell me the president.

\section{A: OK. [We respect you]. Sir. I'm so sorry.}

In this extract, the customer is not satisfied with the agent's services because every time the agent calls the customer, his problems are still not solved. So the customer wants the manager to deal with his complaint. In the front part of this interaction, the customer has already asked the agent to transfer him to the supervisor, and the agent has explained to him that it is beyond his power. Then the customer turns to the company's manager. In line 04 , the agent repeats what he says before "there is no anymore answer". However, the customer doesn't give up and uses an imperative sentence to directly ask the agent to find a line to get to the manager again, which violates the agent's equity rights of not being imposed. Then, the agent makes an apology to the customer to support his equity rights. 
At the same time, the agent also constructs a powerless agent identity. In line 07 , the customer doesn't seem to cooperate with the agent and says he will still be on the line, which violates the agent's equity rights again because this reaction indicates that he still requires the agent to call the manager. In line 10, the agent makes the repetition again to show his being powerless to support his equity rights. In line 11 and 13 , the customer even asks the president of the company and tells the agent he will not leave the phone until the president comes, which is also a violation to the agent's equity rights. The agent has no choice but to make an apology to the customer to construct a powerless agent identity to support his equity rights. As can be seen from this extract, the agent constructs a powerless agent identity through making repetition and making apologies to support his equity rights.

\section{Extract 10}

(Context information: the customer complains about the extra more money he has to pay due to the company's system problem.)

$01 \mathrm{C}$ : The reason that your system, because your computer system has a problem. I now have to pay too high of the amount. (1.0) You're insane?

$02 \mathrm{~A}$ : I know. I'm rea:lly sorry to give you the inconvenience, sir. But now, we do not have any solutions for you about your case. We just give you the ser...

$03 \mathrm{C}$ : Okay. [There has] to be a solution, a solution to find the way to purchase the repay the package. I have 400 which is my (luggage?) to pay. But I have tried to pay for 4 days.

$04 \mathrm{~A}$ : Eh hen. I know, sir.

05 C: I cannot pay 1200 dollars through (???). How would you been for reinvesting? How, how are you going to, to reinvest that if the (title?_) of my trouble for my work? How will this gonna happen?

06 A: Ummm(.) I am really sorry, But now, the system cannot make the order on the website so the IT department is still working to find out the(.) what problem in, and we cannot verify that is the system error. So(.) maybe you can try later because, uh(.)_

In this extract, the customer has paid extra more 1200 dollars for his luggage due to the system problems in the company's website. Then the customer calls to complain about this issue because the company has not given a satisfying answer to the customer in four days. In line 01 , the customer directly criticizes that it is the company's system problem that makes him pay this extra money, and calls the customer "insane", which is face-threatening to the agent and also violates the principle of mutual respect in communication. According to Ran (2012), mutual respect is also an embodiment of supporting people's association rights in communication. So in order to support his own association rights with the customer, the agent quickly makes an apology to the customer and explains that they have no solution at this moment because the system is still being repaired, which shows the agent's powerless aspect in helping the customer. However, the customer does not think it is a reasonable account and believes that there is a solution. In line 06 , the agent apologizes to the customer and repeats the reason again to construct a powerless agent identity to support his association rights.

\subsubsection{Support other's equity rights and association rights}

According to Ran (2012), communicators ought to be equal and ought not to be harmed and exploited by their communicators. In complaint response calls, when the customer's interests are harmed, the agents may always offer some compensation to the customers to support the customer's equity rights. In addition, in some circumstances, the customers may show their association with the agents to gain help from the agents. When this happens, the agents may also support the customer's association rights. The following two extracts show the agents construct pragmatic identities to support the customer's equity rights and association rights.

\section{Extract 11}

(Context information: the customer complains about the cancellation of the flight of the company because he has paid extra 1000 more money to change the flight.)

$01 \mathrm{C}$ : 对啊, 因为我们时间来不及嘛。你是去（？）取场票，(取场票是发车急嘛？)）你也知道，像我在 中国是买票的话都下午机票的价格也是非常贵的。这次本来我们是 6 点多的飞机到西宁是 8 点多 的, 到那天回来以后 12 点多, 时间呢倒是觉得无所谓, 但是我觉得呢就是这个价钱, 额 1000 多块 钱, 恩你说多了 1000 多块钱我们也觉得问题不大。关键是对于这个事情呢, 我们觉得心里还是不 舒服。

$02 \mathrm{C}$ : 恩, 恩。我明白您的意思, 先生。针对您这个问题哈, 就是说航班计划性取消这个发生变动这个问 题给您带来这个不便的话也确实很抱歉。那您要求针对这方面给予赔偿的话, 可能针对这个情况暂 
时没有-就是说可能暂时没有经济方面的一个赔偿, 但是呢就说也确实像您刚刚描述的那样子, 就是 说也确实给您带来了很大不便。而且您也给重新买了机票这样一个信息。那现在就是说针对您说赔 偿方面我们这边可能没有这个方面一个赔偿, 但是针对您这个不良体验方面的话我们这边可以分 （？）礼品, 精美飞机模型给你, 给您做一个客户体验, 快递费这些都由南航来承担。因为您是两 个旅客的话我们这边的话就是说给您申请两个礼品, 精美的一个飞机模型给您做一个(空机键? ), 也都希望您能够谅解一下吧, 好吗?

$01 \mathrm{C}$ : Yeah, because we don't have time. Are you going to (?). As you know, if I buy a flight ticket in China, the price of the ticket in the afternoon is very expensive. This time, we plan to go to Xining by plane at about 6 o'clock and arrive there at about $8 \mathrm{o}$ 'clock, and it is about $12 \mathrm{o}$ 'clock after we came back that day. It doesn't matter for the time. What matters is the price, the amount is more than 1000 yuan. Well, the amount is not a big deal. However, we still feel uncomfortable about it.

02 A: Well, well. I see what you mean, Sir. As for your problem, I am really sorry for the inconvenience brought to you by the change of flight schedule. As for your requirements for compensation in this respect, there may be no compensation for this situation-that is to say, there may be no economic compensation at present, but it is indeed like what you just described, that is to say, it has really brought you a lot of inconvenience. And you also bought a new ticket. And we may not have a compensation for this aspect in terms of compensation for you, but we can give a model plane to you as a gift for your bad experience. The express fees are all borne by our company. Because there are two passengers, we can apply for two model planes for you. I hope you can understand us.

In this extract, the customer has paid 1000 extra more money to change his flight to another airline company due to the cancellation of the flight in the company. So the customer calls to complain about this issue. In line 01, the customer states his dissatisfaction with the agent. Then in line 02 , the agent apologizes to the customer and acknowledges the inconvenience brought to the customer to construct a considerate agent identity. In addition, in order to make up for the loss the customer suffers, the agent offers to give the customer a model airplane as compensation to support the customer's equity rights. Because the cancellation of the flight is abrupt and it is because of this cancellation that causes the customer's loss, which harms the customer's interests. "In communications, communicators ought to be equal and ought not to be harmed and exploited by their communicators" (Ran, 2012, p.4). As the service representative of the company, the agent should support the customer's equity rights and interests. When the customer's interests and equity rights are harmed, the agent may offer some compensation to support the customer's equity rights. As can be seen from line 02 in this extract, the agent firstly apologizes to the customer and acknowledges their problems and then offers to give a model airplane to the customer to show his consideration to the customer. In so doing, the agent constructs a considerate agent identity to support the customer's equity rights.

\section{Extract 12}

(Context information: the customer is hit on his head by a suitcase on the flight. However, the security guard provides false confession to the police.)

$01 \mathrm{~A}$ : OK. I know I will transit it to cabin crew and check it again. I'm so sorry to hear what you have suffered.

$02 \mathrm{C}$ : Thank you.

03 A: You're welcome.

\section{$04 \mathrm{C}$ : I just want you know that 我是你的金卡会员 (I am the golden card member in your company).}

$05 \mathrm{~A}$ : Yeah, golden membership. Thank you for your support.

06 C: That's why I know how to reflect. I know (???). I know all of these. And I know people want to prevent something happen by talking through it. Don't involve more people. Don't make the issue bigger. Because they just want to make things good for everybody.

$07 \mathrm{~A}$ : OK, sir, I know. We will try our best to help you and [We]'ll contact you in a few workdays. Thanks for all the information you support. Thank you.

In this extract, the customer is hit on his head by a suitcase on the flight. However, the security guard treats the customer badly and provides false confession to the police. So the customer calls to the agent to seek help and provides more details. After getting the details of the accident, the agent makes commitment that he will transit the details to the cabin crew and check it again in line 01 and apologizes to the customer to show his sympathy to the customer. As can be seen from the customer's reply in line 02, the customer shows his gratitude to the agent. In addition, in line 04 , the customer mentions that he is the golden membership of the company. In so doing, the 
customer closes the relationship gap between these two parties and shows his association with the agent through his emotion sharing. In line 06, the customer further stands in the company's feet to consider the company's interests, which also shows his association with the company. In order to support the customer's association rights, the agent constructs an accountable agent identity through making commitment to the customer that they will try their best to help the customer and will contact the customer. So this extract shows the agent constructs an accountable agent identity through making commitment to support the customer's association rights.

\subsubsection{Support Interactional Goals}

Interactional goals refer to communicator's communicative purposes in interaction. People often have certain communicative purposes when they communicate with others. These purposes can be relational or transactional.

\section{Extract 13}

(Context information: the customer says the agent's English is very poor when handling complaints.)

$01 \mathrm{~A}$ : This is XXXX Complaint Centre. (.) Are you available to talk now?

$02 \mathrm{C}$ : Yeah, but your English is not very good.

$03 \mathrm{~A}$ : (Inhale) OK, thank you, sir, because we have done the complaint, because you have a problem in ticket..(Interrupted)

$04 \mathrm{C}$ : [No]. [Wait]. Your Engli:sh is really bad, OK? So if you're on the customer complaints, your English needs to be a lot better so that I can understand it, because at the moment, I don't understand it.

$05 \mathrm{~A}$ : OK, because we just want to tell you that the seat has been changed. (.) But we couldn't help you change it. translate... (Interrupted)

In this extract, the agent calls back to handle the customer's complaints. However, when the agent greets with the customer and wants to know more details about the customer's problems. The customer does not cooperate with the agent and begins to complain about the agent's English proficiency. As can be seen from line 03, the agent has no choice but to thank the customer and begins to make explanation about the customer's complaints to get down to the business. However, the customer seems not to give up and continues to talk about the agent's English. In line 05 , the agent makes explanation about the complaints again to change the topic to deal with the complaints. The interactional goal of the agent in this extract is to handle the customer's complaints, to solve the customer's problems. To support this interactional goal, the agent chooses to construct an accountable agent identity by making explanation to the customer about the customer's complaints. In this way, accelerating the complaint handling.

\subsection{Discussion}

This study has investigated the customer service agent's pragmatic identity construction in complaint response calls from the perspective of rapport management. By adopting the discourse analytical method, it first identifies the types of identities the agents construct in the context of complaint response calls. And then rapport management strategies are identified from five rapport management domains to see how the agents construct these pragmatic identities. Finally, it examines the interpersonal functions performed by these identities. It has been found that the agents mainly construct four types of pragmatic identities when handling complaints in complaint response calls. These identities include three types of default identities and one type of deviational identity. The default identities are considerate agent, accountable agent and powerless agent. And the deviational identity is layperson. It is not surprising that the agents construct these identities in complaint response calls. Most of time, complaint is triggered by the service failures of the company. It is the customer's dissatisfaction about the misconduct of the company that causes the complaints. In order to pacify and comfort the dissatisfied customers, the agent may always show his/her consideration, respect and empathy to the customer to express his/her understanding of the customer's situations, which aims to produce a positive effect on customer satisfaction. In this way, the agents may construct a considerate agent identity. In addition, the agents are the service agent representative of the company responsible for dealing with customer's problems. Therefore, when handling the customer's complaints, the agents will always show his/her accountability and willingness to address the customer's problems. In this way, the agents may construct an accountable agent identity. However, the power given to the agents by the company is actually very limited. They have to handle the complaints within the company's regulations. When it comes to some complaints that beyond the agent's power, the agents may show his powerless aspect in addressing the complaints. In this way, the agents may construct a powerless agent identity. When handling complaints, the agents may sometimes meet some problems that beyond his/her knowledge scope. Once it happens, the agents may construct a layperson identity. 
Pragmatic identities are constructed through linguistic choices. Data analysis has revealed that the agent mainly employs nine rapport management strategies from four rapport management domains to construct identities. It can be summarized as follows: acknowledging problems, making suggestions and making apologies for considerate agent identity construction; making commitments and making explanations for accountable agent identity construction; making apologies, changing topic and making repetition for powerless agent identity construction; making identity reference for layperson identity construction. Actually, making apologies and making explanations are two of the most frequent strategies the agents employ to construct identities because these two strategies can well attend to the agent's and the customer's face and interests.

Agent's pragmatic identities are constructed to perform these three interpersonal functions, which includes support self quality face and identity face, support other's quality face and identity face; support self equity rights and association rights, support other's equity rights and association rights; and support interactional goals. More specifically, considerate agent identity performs the interpersonal functions of supporting the customer's quality face and identity face, supporting the customer's equity rights and association rights. Accountable agent identity performs the interpersonal functions of supporting self quality face and identity face, supporting the customer's association rights, and supporting interactional goals. Powerless agent identity performs the interpersonal functions of supporting self quality face and identity face, supporting self equity rights and association rights, and supporting interactional goals. Layperson identity performs the interpersonal functions of supporting self quality face and identity face. As can be seen from the data, each type of identity can be used to perform different interpersonal functions and one interpersonal function can also be achieved through different pragmatic identities.

\section{Conclusion}

Building on Spencer-Oatey's (2008) rapport management theory, this study has made a detailed investigation of the agent's pragmatic identity construction in complaint responses. It has been found that the agents mainly construct three default identities (considerate agent identity, accountable agent identity and powerless agent identity) and one deviational identity (layperson identity) in complaint response calls by employing nine rapport management strategies from four rapport management domains. These different pragmatic identities mainly perform three kinds of interpersonal functions: support face needs, support sociality rights and obligations, and support interactional goals. The present study not only interprets the feasibility of rapport management theory in the study of identity construction, but also provides some implications for the agents to construct appropriate identities through specific linguistic strategies when handling complaints, which can not only improve the efficiency of complaint handling, but also can maintain a harmonious relationship with the customers.

Despite the feasibility and practicality of the present study, there are also some limitations in the study. Firstly, the author only collects 42 complaint response recordings, the generalization of the findings in the present study may call for larger data to conduct a more detailed investigation. Secondly, identity identification and rapport management strategies identification in the present study may be somewhat subjective since it is based on a qualitative analysis. Thirdly, the present study only focuses on agent's verbal strategies to construct identities in complaint response calls while neglects non-verbal strategies, non-verbal strategies may also have an influence on identity construction. However, this study does not consider these factors.

Future studies are expected to avoid the limitations mentioned above. In addition, to minimize the subjectivity of our cognitive differences when interpreting the interpersonal functions of the agent's pragmatic identity construction, a face-to-face interview with the agents should be made to understand the agent's motives for identity construction. Future research, if possible, should analyze the interpersonal functions of agent's pragmatic identity construction in combination with the interview results. Last but not least, future research can also combine a quantitative research method to investigate the frequency of each type of identity the agents construct in complaint response calls and demonstrate the reasons.

\section{References}

Anna, S., Daniel, J. M., \& Mount. (2003). The impact of selected customer characteristics and response time on E-complaint satisfaction and return intent. International Journal of Hospitality Management, 22(2), 135-145. https://doi.org/10.1016/S0278-4319(03)00014-8

Antaki, C., \& Widdicombe, S. (1998). Identity as an achievement and as a tool. London: Sage Publications.

Benwell, B., \& Stokoe, E. (2006). Discourse and Identity. Edinburgh: Edinburgh University Press.

Brown, G., \& Yule. (1983). Discourse Analysis. Cambridge: Cambridge University Press. https://doi.org/10.1017/CBO9780511805226

Brown, P., \& Levinson, S. C. (1987). Politeness: Some Universals in Language Usage. Cambridge: Cambridge 
University Press. https://doi.org/10.1017/CBO9780511813085

Bucholtz, M., \& Hall, K. (2005). Identity and interaction: A socio-cultural linguistic approach. Discourse Study, 7(4-5), 585-641. https://doi.org/10.1177/1461445605054407

Chen, Xinren. (2009). The Social Psychological Dimension of Pragmatics. Foreign Languages in China, 6(05), $46-52$.

Chen, Xinren. (2013). Pragmatic Identity: Dynamic Choice and Discourse Construction. Foreign Languages Research, 140(4), 27-32.

Chen, Xinren. (2014). The Study of Identity from the Perspective of Pragmatics: Key Issues and Main Approaches. Modern Foreign Languages, 37(05), 702-710.

Chen, Xinren. (2018). A Critical Pragmatic Analysis of "Identity Pattern" in Commercial Advertisements. Shandong Foreign Language Teaching, 39(05), 24-33.

Chen, Xinren \& Li, Mengxin. (2016). Identity Conflicts and Discourse Strategies in Academic Context: Based on the Analysis of Moderators' Discourse at Academic Conferences. Foreign Languages Research, 33(02):1622.

Davidow, M. (2003). Organizational responses to customer complaint: what works and what doesn't. Journal of Service Research, 5(3), 225-250. https://doi.org/10.1177/1094670502238917

Davies, C. E. (2019). An autoethnographic approach to understanding identity construction through the enactment of sense of humor as embodied practice. Journal of Pragmatics, 152, 200-215. https://doi.org/10.1016/j.pragma.2019.02.010

Doga, I. (2017). Complaint handling on social media: The impact of multiple response times on consumer satisfaction. Computers in Human Behavior, 74, 72-78. https://doi.org/10.1016/j.chb.2017.04.016

Drew, P., \& Walker, T. (2009). Going too far: complaining, escalating and disaffiliation. Journal of Pragmatics, 41, 2400-2414. https://doi.org/10.1016/j.pragma.2008.09.046

Ekström, M., \& Lundström, F. (2014). The termination of complaints in calls to an authority for student support. Journal of Pragmatics, 74, 132-149. https://doi.org/10.1016/j.pragma.2014.09.006

Feng \& Ren. (2019). "This is the destiny, darling": Relational acts in Chinese management responses to online consumer reviews. Discourse, Context \& Media, 28, 52-59. https://doi.org/10.1016/j.dcm.2018.09.003

Guo, Yadong. (2016). Research on Identity Construction of Female Scholars in Academic Discourse. Foreign Languages Research, 33(02):29-32+38.

Ho, V. (2017). Giving offense and making amends: How hotel management attempts to manage rapport with dissatisfied customers. Journal of Pragmatics, 109, 1-11. https://doi.org/10.1016/j.pragma.2016.12.001

Ho, V. (2018). Exploring the effectiveness of hotel management's responses to negative online comments. Lingua, 216, 47-63. https://doi.org/10.1016/j.lingua.2018.10.004

Hutzinger, C. \& Weitzl, W, Z. (2019). Co-creation of online service recoveries and its effects on complaint bystanders. Journal of Business Research. https://doi.org/10.1016/j.jbusres.2019.10.022

Karatepe, O. M. (2006). Customer complaints and organizational responses: the effects of complainants' perceptions of justice on satisfaction and loyalty. International Journal of Hospitality Management, 25(1), 69-90. https://doi.org/10.1016/j.ijhm.2004.12.008

Kevoe-Feldman, H. (2018). The interactional work of suppressing complaints in customer service encounters. Journal of Pragmatics, 123, 102-112. https://doi.org/10.1016/j.pragma.2017.10.018

Li, Chengtuan \& Ran, Yongping. (2015). Study on Identity Construction within Interpersonal Pragmatics: Its Present State, Theoretical Principles and New Directions. Foreign Languages in China, 12(2), 47-54.

Li, Juan. (2016). Research on Acknowledgements in Doctoral Dissertation from the Perspective of Pragmatic Identity. Foreign Languages Research, 33(02), 33-38.

Li, Ying, \& Deng, Liming. (2019). I am what I have written: A case study of identity construction in and through personal statement writing. Journal of English for Academic Purposes, 37, 70-87. https://doi.org/10.1016/j.jeap.2018.11.005

Liao, T, H \& Keng, C, J. (2013). Online shopping delivery delay: Finding a psychological recovery strategy by online consumer experiences. Computers in Human Behavior, 29(04), 1849-1861. 
https://doi.org/10.1016/j.chb.2013.03.004

Marquez-Reiter, R. (2013). The dynamics of complaining in a Latin American for-profit commercial setting. Journal of Pragmatics, 57, 231-247. https://doi.org/10.1016/j.pragma.2013.08.024

Marx \& Engels. (1997). Selected Works of Marx and Engels (vol.1). Beijing: People's Publishing House.

Melancon, J, P., \& Dalakas, V. (2018). Consumer social voice in the age of social media: Segmentation profiles and relationship marketing strategies. Business Horizons, 61(01), 157-167. https://doi.org/10.1016/j.bushor.2017.09.015

Min, H., Joireman, J., \& Kim, H, J. (2019). Understanding why anger predicts intention to complain among high but not low power customers: A test of competing models. Journal of Business Research, 95, 93-102. https://doi.org/10.1016/j.jbusres.2018.10.017

Orthaber, S. (2019). Aggressive humour as a means of voicing customer dissatisfaction and creating in-group identity. Journal of Pragmatics, 152, 160-171. https://doi.org/10.1016/j.pragma.2018.11.002

Orthaber, S., \& Márquez-Reiter, R. (2011). "Talk to the hand". Complaints to a public transport company. Journal of Pragmatics, 43(15), 3860-3876. https://doi.org/10.1016/j.pragma.2011.10.004

Ran, Yongping. (2007). An in-depth Study of the Traditional Topics of Pragmatics and Expansion of Emerging Topics---a Review of the 10th International Symposium on Pragmatics. Foreign Language Education, (06), 6-10.

Ran, Yongping. (2012). Managing and Violating Rappoort in Interpersonal Communication. Foreign Language Education, 33(04), 1-5.

Refiana, L. (2012). Qualitative Analysis about Consumer Complaint Response through Reader's Letter Column in $\begin{array}{lllll}\text { Kompas.com. Procedia-Social and Behavioral } & \text { Sciences, }\end{array}$ https://doi.org/10.1016/j.sbspro.2012.11.095

Ren, Yuxin. (2012). Constructing Identities in Academic Advising Interaction: An Adaptationist Account. Nanjing University: Unpublished doctoral dissertation.

Sierra, S. (2019). Linguistic and ethnic media stereotypes in everyday talk: Humor and identity construction among friends. Journal of Pragmatics, 152, 186-199. https://doi.org/10.1016/j.pragma.2018.09.007

Simon, B. (2004). Identity in Modern Society: A Social Psychological Perspective. Oxford: Blackwell. https://doi.org/10.1002/9780470773437

Spencer-Oatey, H. (2008). Culturally Speaking: Culture, Communication and Politeness Theory. London : Continuum International Publishing Group.

Stryker, S. (1987). Identity theory: developments and extensions. In K. Yardley \& T.Honess (Eds.), Self and Identity: Psychosocial Perspectives (pp. 89-103). New York: Wiley.

Sun, Li. (2015). Study on Pragmatic Identity Construction in English Abstract of Chinese Master's Thesis. Foreign Languages and Their Teaching, (05), 15-21.

Tajfel, H. (1978). Social categorization, social identity, and social comparisons. In Tajfel (Ed.), Differentiation between social groups (pp.61-76). Waltham: Academic Press.

Tracy, K., \& Robles, J. S. (2002). Everyday Talk: Building and Reflecting Identities New York: Guilford Press.

Vöge, M. (2010). Local identity processes in business meetings displayed through laughter in complaint sequences. Journal of Pragmatics, 42(06), 1556-1576. https://doi.org/10.1016/j.pragma.2010.01.016

Yuan, Zhoumin. (2011). An empirical study on pragmatic identity construction of medical consultants from the perspective of adaptation theory. Nanjing university: Unpublished doctoral dissertation.

Yuan, Zhoumin. (2013). On Dynamics of Consultants' Identity Construction in Business Phone-in. Language Teaching and Linguistic Studies, (06):89-96.

Zhang, Haiyang. (2006). Chinese multiculturalism and Chinese identity. Beijing: Ethnic press.

Zhang \& Vásquez, C. (2014). Hotels' responses to online reviews: Managing consumer dissatisfaction. Discourse, Context \& Media, 6, 54-64. https://doi.org/10.1016/j.dcm.2014.08.004

Zhong, Jiabao. (2018). Study on Pragmatic Identity Construction of Graduate Students in Academic English in the New Era. Foreign Languages in China, 15(05), 62-66. 


\section{Copyrights}

Copyright for this article is retained by the author(s), with first publication rights granted to the journal.

This is an open-access article distributed under the terms and conditions of the Creative Commons Attribution license (http://creativecommons.org/licenses/by/4.0/). 